\title{
Combating COVID-19 under Bolsonaro's federalism: a case of intergovernmental incoordination
}

\author{
Fernando Luiz Abrucio 1 \\ Eduardo José Grin 1 \\ Cibele Franzese 1 \\ Catarina lanni Segatto ${ }^{2}$ \\ Claúdio Gonçalves Couto 1 \\ 1 Fundação Getulio Vargas / Escola de Administração de Empresas de São Paulo, São Paulo / SP - Brazil \\ 2 Universidade Federal do ABC / Programa de Pós-Graduação em Políticas Públicas, São Bernardo / SP - Brazil
}

This article analyzes how federalism has affected policy responses to the COVID-19 pandemic in Brazil. Through historical-institutional analysis, the study examines how the model of federalism adopted by President Bolsonaro's government influenced policy responses to the pandemic in the country. In addition, the research points out the existence of two models of federalism in the case analyzed, addressing the outcomes of the confrontation between them. The first model refers to ideas and institutional structures that have emerged since the 1988 Brazilian Federal Constitution with cooperative features and strong federal coordination. The second, named "Bolsonaro's federalism," is based on a dualistic view of intergovernmental relations with little participation of the federal government in reducing territorial inequalities and supporting subnational governments, while centralizing issues of national importance and adopting a hierarchical stance. The study shows that Bolsonaro's government increased the conflict with subnational governments and jeopardized the coordination of policy responses to the COVID-19 pandemic. We conclude that healthcare and federative crises go together and raise a key question: what is the importance of governmental coordination to implement policies to respond to the pandemic and its social and economic effects?

Keywords: COVID-19; federalism; intergovernmental relations; public policies; Bolsonaro's government.

\section{Combate à COVID-19 sob o federalismo bolsonarista: um caso de descoordenação intergovernamental}

Este artigo analisa como o federalismo brasileiro tem afetado o combate à COVID-19. Tendo por base uma análise histórico-institucional do caso brasileiro, busca-se compreender como o modelo federativo construído pelo governo Bolsonaro influenciou as respostas ao combate da pandemia no país, bem como os resultados do confronto de dois modelos federativos nesse processo. De um lado, o ideário e as estruturas institucionais da Constituição de 1988 com características cooperativas e forte coordenação federal. De outro, o federalismo bolsonarista baseia-se numa visão dualista de relações intergovernamentais, com menor participação da União na redução de desigualdades territoriais e no apoio a governos subnacionais, além da postura centralizadora e hierárquica nas questões de impacto nacional. O estudo mostra que o federalismo bolsonarista aumentou o conflito com governos subnacionais e tem descoordenado políticas públicas de enfrentamento à pandemia. Conclui-se que as crises sanitária e federativa caminham juntas e trazem à tona uma questão chave: a importância da coordenação governamental nas políticas públicas de enfrentamento à pandemia.

Palavras-chave: COVID-19; federalismo; relações intergovernamentais; políticas públicas; governo Bolsonaro. 


\title{
Lucha contra el COVID-19 bajo el federalismo bolsonarista: un caso de descoordinación intergubernamental
}

\begin{abstract}
Este artículo analiza cómo el federalismo brasileño ha afectado la lucha contra COVID-19. A partir de un análisis histórico-institucional del caso brasileño, buscamos comprender cómo el modelo federativo construido por el gobierno de Bolsonaro influyó en las respuestas para combatir la pandemia en el país, así como los resultados de la confrontación de dos modelos federativos en este proceso. Por un lado, los ideales y las estructuras institucionales de la Constitución de 1988 con características cooperativas y una fuerte coordinación federal. Por otro lado, el federalismo bolsonarista se basa en una visión dualista de las relaciones intergubernamentales, menos participación de la Unión en la reducción de las desigualdades territoriales y en el apoyo de los gobiernos subnacionales, además del comportamiento centralizado y jerárquico en materias de impacto nacional. El estudio muestra que el federalismo bolsonarista ha aumentado el conflicto con los gobiernos subnacionales y ha descoordinado las políticas públicas para combatir la pandemia. Se concluye que la crisis de salud y la federativa van juntas y plantean una cuestión clave: la importancia de la coordinación gubernamental para implementar políticas públicas enfocadas en enfrentar la pandemia y sus efectos sociales y económicos.
\end{abstract}

Palabras clave: COVID-19; federalismo; relaciones intergubernamentales; políticas públicas; gobierno de Bolsonaro.

\section{INTRODUCTION}

The fight against the ongoing pandemic has been affected by several factors. Among them are the implications of the intersections between political actors and the institutional dynamics of public policies. In this area, a recurring aspect of the epidemiological crisis is the dimension of territorial politics (Broscheck, Petersohn, \& Toubeau, 2017), which affects federations and countries with federalized mechanisms (Baldi, 1999; Swenden, 2006).

The effect of territorial politics is evident in several countries, such as the United States, Italy, Spain, Germany, India, Mexico, and Brazil. In these countries, the relations of conflict and cooperation between the national sphere and subnational levels of government have shaped recent public health policies against COVID-19 to a good extent. In some of these instances, successful federal solutions account for part of the achievements in countering the pandemic, as in the German case (Pleitgen, 2020). In the US and Brazil, on the contrary, there were mistakes in the fight against COVID-19, particularly because of intergovernmental conflicts and incoordination.

This article examines how federalism has affected the fight against COVID-19 in Brazil under the presidency of Bolsonaro. It aims to show that intergovernmental relations were already undergoing a process of change before this crisis, but its effects were intensified during the pandemic, when the need for a coordinating role to be played by the Federal Government became more evident. This is the case, as health crises require strong government coordination, especially in federal countries, as Paquet and Schertzer (2020) show through the concept of intergovernmental complex problem. For that reason, scholarship is emerging, exploring how the territorial dimension impacts policies adopted to tackle the new coronavirus (De la Cruz et al., 2020; OECD, 2020; Tulich, Rizzi, \& McGaughey, 2020).

The analytical framework is based on the relationship between actors, institutions, public policies, and federalism (Pierson, 1995; Benz \& Broschek, 2013). Based on this general parameter, the federative coordination analysis in the Bolsonaro Government points out that, in the fight against COVID-19 in Brazil, there was a clash of two federative models. On the one hand, the ideology and structures of the 
1988 Federal Constitution (Constituição Federal de 1988, CF/88), based on cooperative features and strong federal coordination. On the other, the Bolsonaro's federalism, guided by a heavily centralized and hierarchical vision on issues with a national and dualistic impact on intergovernmental relations, which decreases the Federal Government's stake in mitigating territorial inequalities and assisting sub-national governments.

Hence, three fundamental questions emerge: what proposals and effective federalism changes under Bolsonaro have been intensified by the pandemic? Given this, what are the federative continuities and new strategies adopted by sub-national governments - especially states - that make a difference in the federative game? Finally, what is the impact of these intergovernmental relations on public policies against COVID-19? The latter shall be the main contribution of the paper to the field of Public Administration.

\section{METHODOLOGICAL GUIDELINES}

This study is based on a qualitative and historical-institutional analysis that relies on two temporalities. The first one concerns the thirty years of intergovernmental relations post-1988 and builds on the systematization of the already consolidated literature on the subject. The second refers to the current process, in which an attempt is underway to change the pattern of territorial power distribution in public policies and their specific implementation in the fight against COVID-19. To better understand this inconclusive phenomenon, we selected critical sets of beliefs and events (Capoccia \& Kelemen, 2007) that are emblematic of the Bolsonarist attempt to shift Brazilian federalism, as well as the reactions to this model.

The discussion about COVID-19 as a critical event is the "finish line" of an assessment according to which the Bolsonaro government has been seeking, from the outset, to modify intergovernmental relations, a process that finds its most intense expression during the pandemic. In counterfactual terms: if the pandemic has not arisen, would this confrontation not exist either? Our answer is no because it has been ongoing since 2019, the level of confrontation has been escalating, and, with the outbreak of the pandemic, it has only accelerated an already unfolding process. Given the complexity of the health phenomenon, the negative consequences of the Bolsonarist ntergovernmental pattern are amplified.

A historical-narrative analysis was carried out to support the longitudinal reading, since it is only possible to discuss the Bolsonarist federalism in contrast to the institutional design post-1988, based on the cooperative model. In the analysis of the federative coordination during the pandemic, process tracing was the tool of choice, a qualitative method that allows the reconstruction of a chain of events still in progress (Beach \& Pederson, 2013). Thus, the narrative of "circumstantial statements" and documents constitutes the possible and necessary resource to assess an ongoing phenomenon, since it offers an insight into the federative game adopted by sub-national entities and the federal government.

Following that, a documentary analysis (legislation and statements by representatives of the federal government, states, municipalities, the National Congress, the Judiciary) and media coverage was carried out, capturing the steps of the Bolsonaro government since its beginning, with a special focus on the first months of the pandemic (February to June 2020). The reference to the contents covered in the press would lack analytical breadth and explanatory power without the historical-narrative benchmark presented in Box 1, which outlines the trajectory of federal government actions before and during the pandemic. All initiatives are driven by the same logic of revision of the cooperative federalism stemming from the 1988 Federal Constitution. 


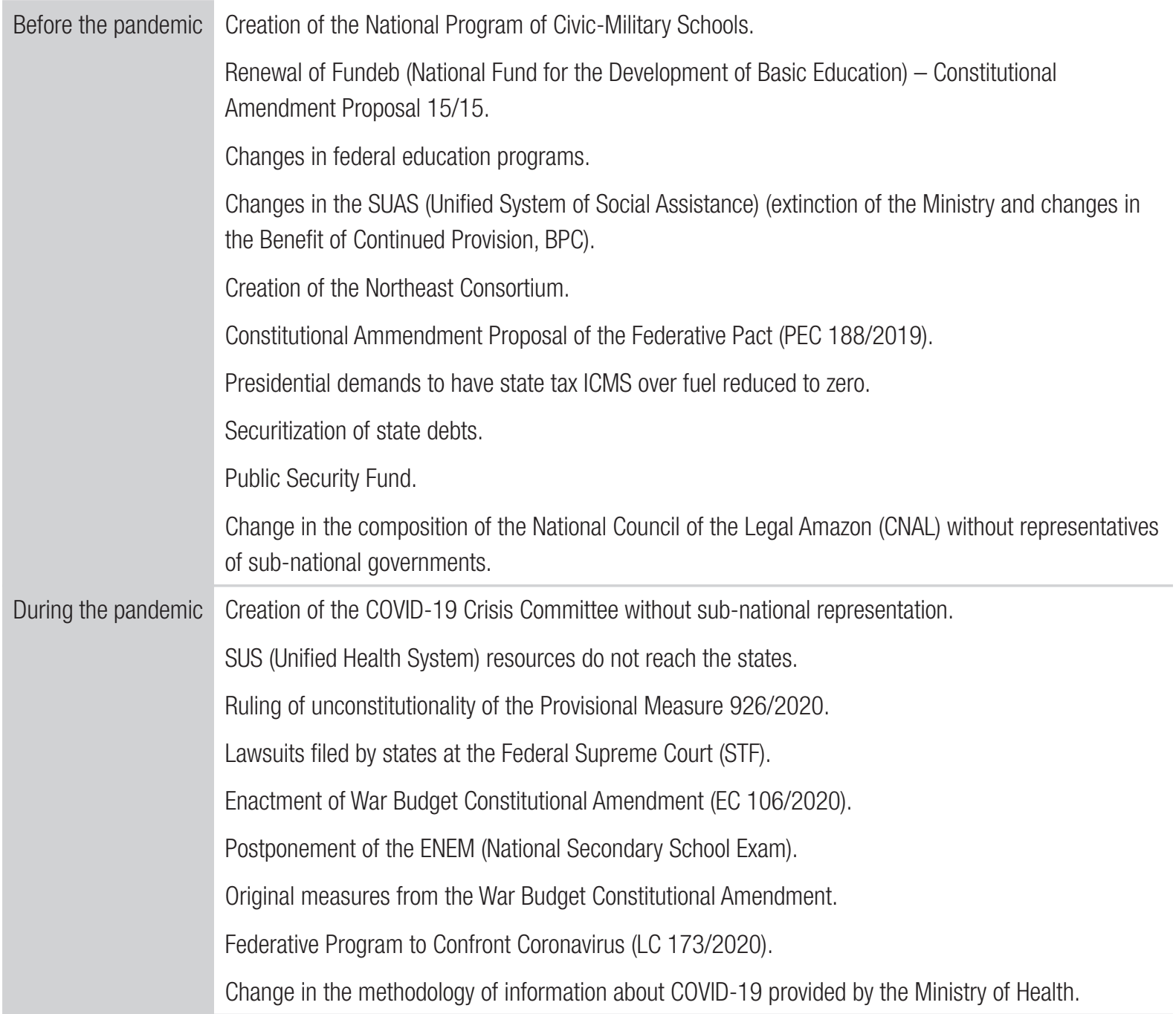

Source: Elaborated by the authors.

\section{MODELS OF FEDERALISM AND INTERGOVERNMENTAL COORDINATION}

In the study of public policies within federalism, intergovernmental coordination is crucial, since it is not easy to reconcile the coexistence between autonomy and interdependence that shapes federations and their decision-making process (Pierson, 1995). Here, there are two ideal types in dispute: the dual and cooperative models.

Dual federalism assumes that each entity has strict constitutional autonomy over different areas to prevent the centralization of power (Loughlin, Kincaid, \& Sweden, 2013). Its premise is that local governments spend more efficiently, are more accountable to their constituencies, and their public policies are more responsive to local particularities. Federative coordination would be contingent, circumstantial and, ultimately, unnecessary, as it would be detrimental to efficient decision-making and resource allocation. 
Today, the paradigmatic case of dual federalism is the USA. After decades of growth of a rather collaborative model (1930 to 1980), President Reagan changed the federative course, decentralizing state functions (devolution powers), as well as reducing the federal engagement in federative assistance and articulation. This dualistic pattern became hegemonic, leading to grown inequality and interstate competition (Kettl, 2020).

In the cooperative model, shared authority combines sub-national autonomy with national coordination. Its spread followed the Welfare State expansion after World War II (Obinger, Leibfried, \& Castles, 2005). To ensure universal rights, federations combined centralized processes (such as financing, regulation, and induction) with decentralized and autonomous implementation of public policies. Thus, the cooperative model does not oppose centralization and decentralization, but understand them as a combination and not as an opposition (Broschek, Petersohn, \& Toubeau, 2017).

Instead of dualism, what is required is coordination aimed at shared goals in order to reduce duplication, overlapping, and territorial inequalities. This process often involves modalities of participation and protection of sub-national governments from federal decisions, especially through intergovernmental forums that minimize or prevent unilateral actions, effectively working as federal safeguards (Schnabel, 2015). The COVID-19 crisis made clear the importance of intergovernmental coordination to combat the pandemic (OECD, 2020; Tulich, Rizzi, \& McGaughey, 2020). In the United States, however, the Trump government has radicalized the dualist model by holding states fully accountable or vying with them for prominence. The spread of the disease was overwhelming. This approach gave rise to the idea of "Darwinist Federalism," which puts entities against each other (Cook \& Diamond, 2020; Geltzer, 2020). In this context, national leadership is essential because, after all, "state boundaries mean very little to the virus," as said Andrew Cuomo, governor of New York.

In Brazil, the fight against COVID-19 highlighted the conflict between these two conceptions of federalism, opposing the cooperative model, built upon the legacy of $\mathrm{CF} / 88$, and the Bolsonarist project, similar to Trumpian dualism, based on the slogan "More Brazil, Less Brasilia," i.e., less federal involvement in public policy.

\section{BRAZILIAN FEDERALISM POST-1988: A BLEND OF COORDINATION AND AUTONOMY}

American dualism originally inspired the Brazilian Federation. The constitutional design of 1891 proposed considerable state autonomy, little intervention by the Federal Government and no federative coordination (Abrucio, 1998). With the rise of Vargas to power, a major transformation of federalism began, as the Federal Government's role grew continuously, especially in the authoritarian periods of the Estado Novo and the Military Regime (Arretche, 2012). This centralized power weakened federalism and did not result in cooperation, since sub-national governments were kept away from major political and public policy decisions.

Re-democratization changed the previous federal model, granting states and municipalities greater political, administrative, and financial autonomy. However, this decentralization was counterbalanced by national policies to expand public policies and combat inequality. Thus, the Union had an important role in federal coordination through regulation, induction, and funding (Abrucio, 2005; Arretche, 2012). Implementation was entrusted to sub-national governments, thus making them pivotal in the expansion of welfare policies (Grin \& Abrucio, 2018). 
The post-1988 federative arrangement made it necessary to calibrate national welfare targets with decentralized and autonomous implementation. For that, the creation of public policy systems has also ensured the participation of sub-national governments in the federative decision-making process (Franzese, 2010). The federative cooperation originating from the $\mathrm{CF} / 88$ progressed incrementally but did not follow similar paths or yield comparable results in all areas. In this process, all presidents engaged in dialogue with states and municipalities to strengthen the federative pact and expand social policies.

In the healthcare sector, the most paradigmatic case, the SUS, was built in the 1990s. The model was based on national guidelines related to the regulation and resource redistribution, decentralized implementation, and institutionalized arenas for social participation and intergovernmental negotiation (Franzese \& Abrucio, 2013). SUS subsequently inspired the creation of SUAS in 2005, also grounded in social participation, resource redistribution, federative forums, and decentralized and hierarchically structured services (Bichir, Simoni, \& Pereira, 2020).

In the realm of primary education, the $\mathrm{CF} / 88$ established the concept of a collaborative regime to deal with the duality of service provision and low intergovernmental cooperation (Abrucio, 2010). Nevertheless, intergovernmental coordination did not occur immediately, because the Federal Government's technical and financial assistance to sub-national governments only grew in strength after 1996 when minimum national parameters were established for the redistribution of resources, as well as for monitoring and evaluation of results (Segatto \& Abrucio, 2018). However, the lack of institutionalized federative forums resulted in a weaker system of articulation when compared to what had been attained in healthcare and social assistance areas. Even so, all federal administrations engaged in negotiation with the National Union of Municipal Education Officers (Undime) and the Council of State Secretaries of Education (Consed).

The Brazilian Federation still suffers from fragmentation, overlapping, competition, and fragile cooperation in some sectors and at the territorial level (Grin \& Abrucio, 2017). However, even with these problems, it has been making strides in enhancing intergovernmental coordination and cooperation in policy implementation. This incremental and incomplete transformation of Brazilian federalism was challenged by President Bolsonaro, who, since taking office, has sought to establish a dualist model of federalism, similar to what has been in place in the United States. The outbreak of the pandemic has exposed Bolsonaro's agenda and exacerbated conflicts between the Federal Government, on one side, and municipalities and especially states, on the other, thus increasing intergovernmental incoordination.

\section{THE DRIFT OF BOLSONARIST FEDERALISM: MOVING AHEAD AND BACKWARDS}

Bolsonaro was elected president on a platform opposing the political system and the so-called "old politics." He had already opposed the re-democratization of the country by constantly championing the military regime as a parliamentarian, and continued to do so after he was elected president (Campos, 2019). His government's major adversaries are the ideals of the $C F / 88$, especially the expansion of government activity resulting from the advancement of citizenship rights and the checks and balances reinforced by the new constitutional framework. His neo-populist project defends a form of democracy without mediation or institutional supervision of the relations between the government and the people (Urbinati, 2019). 
Cooperative federalism, a central feature of $\mathrm{CF} / 88$, was also hit by the Bolsonarist vision with the slogan "More Brazil, Less Brasilia." Apparently connected to the transfer of power to those who should have it, this catchphrase underpins a view of the state that combines economic ultra-liberalism with political anti-liberalism. The first proposes a drastic reduction in government intervention, thereby rendering even inequality secondary; the second seeks to weaken institutional controls in the name of an imperial presidentialism, allied to a Schmittian stance on politics, which holds opponents as enemies to be destroyed (Schmitt, 1992).

Grounded on this, Bolsonaro followed the logic of federative tripe. The first pillar relates to the rigid division of functions between levels of government. Responsibility should be transferred to states and municipalities at the same time as the Federal Government's role in funding and assisting the reduction of territorial inequalities is drastically reduced. The assumption is that states and municipalities are more efficient in resource allocation decisions, so the Federal Government should intervene minimally. The result would be greater inequality across sub-national governments in terms of service provision.

The second pillar reinforces dualism through an autocratic concentration of decisions that affect sub-national entities in the hands of the Federal Government. There is hardly any room for dialogue, negotiation or sub-national participation in federal programs. There are several examples, but the most serious instance concerns the Amazon region: the council created to address the problems in this area excluded governors of the region from the governance structure.

The concept of Bolsonarist federalism also encompasses, as its third pillar, intergovernmental confrontation and the constant struggle against real or imagined adversaries. It enhances the logic of war to stir up its constituency and stamp out an anti-system position. The greatest among these enemies are the institutions themselves and their respective leadership, since the Bolsonarist approach to presidentialism repudiates institutional negotiation and the checks and balances of the Brazilian state, including federalism.

Following this political logic, Bolsonaro confronted the Federation for two reasons. First, the rejection of Bolsonarist policies by sub-national entities. Since states and municipalities are primarily responsible for policy implementation in the social domain, they can alter the course of decisions taken in Brasilia. This is intensified with the presidency's dispute with mayors and, above all, governors, perceived as actors with the power to engage public opinion, the National Congress and the Supreme Federal Court (STF) in federative disputes, in addition to being able to become electoral competitors themselves or allies of the president's greatest electoral opponents. Throughout the pandemic, this federative confrontation has become widespread and sub-national governments have issued letters of repudiation against federal government decisions.

The combined compartmentalized, autocratic, and confrontational federative logic became evident with the pandemic. However, previous critical events had already brought this logic of Bolsonatist federalism into focus on four important spheres. The first one in the realm of public policies, in which efforts were made to dismantle the formal and informal cooperative dynamics. A striking example was in education, as the Ministry of Education utterly disregarded the sub-national governments' positions on issues such as the expansion of civic-military schools, literacy programs, and actions adopted in reaction to the COVID-19 pandemic. In response, mayors and governors also made decisions disregarding Federal Government's proposals. 
This type of federative conflict also arose in other sectors. With regard to the environmental policy implemented in the Amazon region, state governors were repelled. In public security, the Ministry of Justice abandoned the Unified Public Security System (SUSP), reducing cooperation with states (Lima \& Bueno, 2020). In the most dramatic case, the fight against the COVID-19 pandemic, there was a frontal clash between the Bolsonarist model and the SUS.

The second critical event concerns the legislative agenda, particularly the "Constitutional Ammendment of the Federative Pact" (PEC 188, 2019). It is informed by the triad "unburden, unlink, and untie," and aims to make the budget more flexible by devolving to the National Congress the protagonism over allocation decisions made by federative entities. However, the concept of "More Brazil, Less Brasilia" reduces the importance of federative coordination and tends to increase regional inequality. This is a new agenda, in which the bond between federalism and nation becomes meaningless.

A third critical event was the change in the stance of the STF in judging conflicts of competence between the Federal Government and sub-national governments. Historically, the tendency was to decide in favor of the Federal Government (Halberstam, 2008). Canello (2017) points out that, from $\mathrm{CF} / 88$ to 2015 , out of 920 cases on intergovernmental conflicts, $81 \%$ were judged favorably to the Federal Government and only $13 \%$ favorably to states. With Bolsonaro, however, the STF has clearly decided in favor of sub-national entities. In the most important of these decisions, the Supreme Court decided that the Federal Government, states, and municipalities have concurrent competence to act on health issues and may establish restrictive measures to combat the pandemic without the endorsement of the federal government.

Finally, as a hallmark of the reaction to the Bolsonaro's federalism, the Governors' Forum and the Consortium of the Northeast strengthened horizontal cooperation and filled gaps left by the Federal Government. The crisis generated by the COVID-19 pandemic underscored the need for greater collaboration and turned these arenas into a counterweight to presidential initiatives, especially as governors were more adherent to social isolation, as opposed to the omission of the presidency in this regard.

\section{THE FIGHT AGAINST COVID-19 AND BOLSONARIST FEDERALISM: A PARADIGM OF INTERGOVERNMENTAL INCOORDINATION}

In the fight against COVID-19, the Bolsonarist federative logic has acquired a more dramatic feature, since the pandemic is a complex intergovernmental problem, requiring even more intergovernmental coordination than ordinary policies. Instead of changing this path, President Bolsonaro radicalized his federative proposal. The compartmentalized, autocratic, and confrontational model was strengthened, while sub-national governments, especially governors, reacted by reaffirming the cooperation and activation of SUS as a paradigm of health governance. Nevertheless, the logic of reducing federal coordination prevailed.

The first point to highlight is the divergence between the President and the Ministry of Health, ending in the resignation of Minister Henrique Mandetta. Just after the outbreak of the crisis, Mandetta had assumed the role of SUS leader, a position that put him in the spotlight. After getting fired, he wrote the following tweet: 
I have just heard from President Jair Bolsonaro the news of my dismissal from the Ministry of Health. I want to thank the opportunity given to me, to be the manager of our SUS, to put in place a project to improve the health of Brazilians and to plan the response to the coronavirus pandemic, the great challenge that our health system is facing [...] (our emphasis).

Mandetta's praise of the SUS, on two occasions, is significant, since the former minister had worked in the private health sector. This shows that polarization in the current government can be observed not only revolving around the dichotomy of social isolation versus economic recovery, but also as a resilience of the institutional arrangements created with the $\mathrm{CF} / 88$ against the new dynamics of Bolsonaro's federalism. In the polarization between Bolsonaro and Mandetta, two opposing views of federalism were evident: the CF/88, expressed by the SUS, and the new approach, combining devolution powers and autocratism when dealing with sub-national demands.

There was institutional resilience, as federal arrangements still count greatly, even though they now operate in a less consensual way. The president of the National Council of State Secretaries of Health (Conass) has been sidelined from the decisions of the Ministry of Health. Mandetta's protagonism and the isolation of his successor, Nelson Teich, have been overwhelming in a system based on intergovernmental agreement. At the outbreak of the pandemic, governors and mayors declared that the resources were not reaching them, something unusual for the SUS, considering its long history of operational fund-to-fund transfers (Bertoni, 2020). The federative disarray deteriorated with the arrival of Minister Teich. The representative of Conass, the main structure of the SUS for dialogue and federative negotiation, was not even invited to attend his inauguration (Conass, 2020).

The intergovernmental lack of coordination in the fight against COVID-19 escalated with the conflict between the president and governors, which was made explicit in the adoption of measures for social isolation. Three factors converged on this issue: 1) the option of the Bolsonarist federative project for devolution powers; 2) the framework of the $\mathrm{CF} / 88$ rules and its combination of cooperation and autonomy; 3 ) the path of public policies. In a federation like Brazil, with its highly consensual political system, this debate reached the STF.

Regarding the option for devolution powers, Bolsonaro disengaged from the action to fight COVID-19 and took his time to issue any statement about the virus. Since the beginning concerned about the economy, he has minimized the seriousness of the situation by declaring as oversized the destructive power of the virus (Vasconcelos, 2020). In the case of federations, such an omission may preempt public policies: pioneering sub-national initiatives in a certain area, which would pose difficulties for subsequent federal efforts due to the institutionalization of the policy over time (Pierson, 1995). This is exactly what happened in the decision in favor of social isolation, which was ultimately taken by the governors.

The states' actions triggered an escalation in the confrontational tone of the president's discourse, who claimed that "there are certain governors taking extreme measures, beyond their authority, such as closing airports, highways, malls and fairs." And at a press conference, he provocatively pushed further: "There is a state government that has done everything but declared independence from Brazil". As a reaction, in documents signed almost unanimously, the governors strongly criticized the Federal Government's centralizing stance and its rejection to dialogue (Soares, 2020).

Choosing confrontation, Bolsonaro threatened to relax unilaterally the isolation measures adopted 
by the governors but was disallowed by the STF in a precautionary measure proposed by the Brazilian Bar Association $(\mathrm{OAB})$. The decision was based on the shared authority in the area of healthcare (article 23 of FC/88), embedded in the cooperative federalism inherent to the Constitution.

As for the policy path, the pandemic put two models of federalism against each other. Healthcare is the area that best represents the institutional arrangement intended by the $\mathrm{CF} / 88$ in the articulation between public policy and federalism: cooperation, fund-to-fund transfer of resources, universalization of healthcare and gratuity. This path is being challenged by the Bolsonarist project of federalism.

The COVID-19 Crisis Committee, without any state or municipal representatives, illustrates this conception of a radicalized dualist federalism with centralized command. At the same time, the governors' reaction in upholding their initiatives and defending the SUS is positive for federalism. The pandemic has accelerated and unraveled a federative interplay that was already underway, whose disputes are organized around the dualistic and cooperative models.

The example that best illustrates this situation is the adoption of a Complementary Law (LC 173/2020), which "institutes the Federative Program to Confront Coronavirus." The main focus of the law is to relax some of the limits stipulated in the Fiscal Responsibility Law (LRF), in addition to those already made flexible by Article 65 of the LRF itself in cases of public calamity, and to establish criteria for the distribution of $\mathrm{R} \$ 60$ billion in federal transfers to states and municipalities (40\% based on the illness incidence rate and $60 \%$ based on a population-based criteria). Two things stand out: the law was enacted on May 27th and contains a provision preventing aid from being granted to a municipality or state that does not waive its legal claim against the Federal Government for financial aid related to the coronavirus.

The date is striking, showing that it was only at the end of May that the Federal Government decided to organize the distribution of resources. The delay was due to the fact that it was first necessary to arrange for extra resources - something that was made possible with the approval of Constitutional Amendment 106, on May 7th, 2020, which instituted the so-called "war budget." That it was done by law is another surprising aspect, since the SUS usually adopts its decisions by means of federative forums consisting of members of the Administration.

Since the 1990s, the Interagency Commissions have been deciding on the resource distribution through basic operating rules issued by the Ministry of Health. Adoption by law is indicative of the prominence of the National Congress, as states and municipalities have improved their channels of communication in the current scenario. Another important aspect regarding legal claims is that it reveals not only the hierarchical approach of the Federal Government to intergovernmental relations but also highlights how fund-to-fund SUS transfers were not effectively working under the Bolsonarist logic of devolution powers.

The circumstantial decline of the role played by the Federal Government has added to the intergovernmental incoordination and inequality between states and municipalities. The intergovernmental conflict made it difficult to reach national decisions, such as regulations on social isolation, distribution of resources, and medical equipment. In this context, the Consortium of the Northeast and states such as Sao Paulo and Maranhão took decisions that produced horizontal and vertical competition for scarce supplies in the fight against COVID-19. Even with regard to other domains, such as economic and educational policies, there was strictly no federative coordination of efforts to tackle the pandemic. 


\section{CONCLUSION}

Brazilian federalism has changed substantially in recent decades. The end of the Military Regime and the $\mathrm{CF} / 88$ made it possible to set the foundations for a democratic, decentralized, participatory, and more cooperative federation, which altered the previous authoritarian and centralized pattern.

However, the path opened by the Bolsonarist federative logic unbalanced the pillars of the institutional framework that emerged after 1988, with its gamble on a dualistic and autocratic model, based on intergovernmental confrontation. The disputes between the president and governors over authority to decide about social isolation, for example, are evidence of this.

As a result, the Bolsonaro's federalism project had significant negative effects on the fight against COVID-19. The culmination of this process took place when the Ministry of Health accused states of lying about the number of deaths from the pandemic, ceasing to inform the public about the number of victims and infected with the same frequency as before, and thus placing the entire SUS cooperative model under suspicion. The confrontation and the intergovernmental incoordination, prompted by the lack of leadership of the Federal Government, resulted in a waste of resources, overlapping of initiatives, reduction of the gains of scale that come from federative coordination, and an impairment to the guarantee of social rights that had been achieved over the years. The fact is that this federative disarray was one of the main causes for the terrible results achieved in the numbers of people who became ill and died. These figures have thrown the country into an uncomfortable position on the international stage.

However, a different scenario may emerge from the health crisis: learning about the importance of cooperative federalism in the country, not only in the daily operation of public policies but above all in situations of complex intergovernmental problems. The post-pandemic period is likely to produce very complex situations in terms of social and economic crisis, thereby further reinforcing the importance of intergovernmental cooperation in the field of healthcare, in addition to other areas, such as education and social assistance, thus mobilizing all of them in the reconstruction of Brazilian society.

Whether the country will really learn that preserving cooperative federalism is essential to avoid further failures is still an open question. But the example of intergovernmental incoordination in the fight against COVID-19 will be etched as a sad chapter in our history. 


\section{REFERENCES}

Abrucio, F. L. (1998). Os Barões da Federação: os governadores e a redemocratização brasileira. São Paulo, SP: Editora Hucitec.

Abrucio, F. L. (2005). A coordenação Federativa no Brasil: a experiência do período FHC e os desafios do governo Lula. Revista de Sociologia e Política, 24, 41-67.

Abrucio, F. L. (2010). A dinâmica federativa da educação brasileira: diagnóstico e propostas de aperfeiçoamento. In R. P. O. Oliveira, \& W. Santana (Orgs.), Educação e federalismo no Brasil: combater as desigualdades, garantir a diversidade (pp. 39-70). Brasília, DF: UNESCO.

Agranoff, R. (2007). Intergovernmental Policy Management: cooperative practices in federal systems. In M. A. Pagano, \& R. Leonardi (Eds.), The dynamics offederalism in national and supranational political systems (pp. 248-285). New York, NY: Palgrave Macmillian.

Arretche, M. T. S. (2012). Democracia, federalismo e centralização no Brasil. Rio de Janeiro, RJ: Editora FGV.

Baldi, B. (1999, setembro). Beyond the FederalUnitary Dichotomy (Working Paper 99-7). Berkeley, CA: University of California, Berkeley. Retrieved from https://escholarship.org/uc/item/05b607ng

Beach, D., \& Pedersen, R. B. (2013). Process-Tracing Method. Foundations and Guidelines. Lansing, Michigan: University of Michigan Press.

Benz, A., \& Broschek, J. (2013). Federal Dynamics Continuity, Change, and the Varieties of Federalism. Oxford, UK: Oxford University Press.

Bertoni, E. (2020, April 15). Os erros e acertos de Mandetta, em duas análises. Nexo Jornal. Retrieved from https://www.nexojornal.com. br/expresso/2020/04/15/Os-erros-e-acertos-deMandetta-na-Saúde-em-duas-análises

Bichir, R., Simoni, S., Jr., \& Pereira, G. (2020). Sistemas Nacionais de Políticas Públicas e seus efeitos na implementação: O caso do Sistema único de Assistência Social (Suas). Revista Brasileira de Ciências Sociais, 35(102), e3510207. Retrieved from https://doi.org/10.1590/3510207/2020
Broschek, J., Peterson, B., \& Toubeau, S. (2017). Territorial Politics and Institutional Change: A Comparative-Historical Analysis. Publius: The Journal of Federalism, 48(1), 1-25. Retrieved from https://doi.org/10.1093/publius/pjx059

Campos, J. P. (2019, November 01). Doze vezes em que Bolsonaro e seus filhos exaltaram e acenaram à ditadura. Veja. Retrieved from https://veja.abril.com. br/politica/doze-vezes-em-que-bolsonaro-e-seusfilhos-exaltaram-e-acenaram-a-ditadura/

Canello, J. (2017). Judicializando a federação? O Supremo Tribunal Federal e os atos normativos estaduais (Doctoral Dissertation). Instituto de Estudos Sociais e Políticos, Universidade do Rio de Janeiro, RJ.

Capoccia, G., \& Kelemen, D. (2007). The Study of Critical Junctures: theory, narrative, and counterfactuals in historical institutionalism. World Politics, 59(3), 341-369.

Conselho Nacional de Secretários de Saúde. (2020, April 17). Ministro Nelson Teich reforça a importância da gestão tripartite no SUS a telefonema a Alberto Beltrame. Retrieved from http://www.conass. org.br/ministro-teich-reforca-a-importancia-dagestao-tripartite-no-sus-em-telefonema-a-albertobeltrame-2/

Cook, N., \& Diamond, D. (2020, March 31). 'A Darwinian approach to federalism': States confront new reality under Trump. Retrieved from https:// www.politico.com/news/2020/03/31/governorstrump-coronavirus-156875

Emenda Constitucional no 106, de 7 de maio de 2020. (2020). Emenda Constitucional $n^{\circ} 106$, de 7 de maio de 2020. Institui regime extraordinário fiscal, financeiro e de contratações para enfrentamento de calamidade pública nacional decorrente de pandemia. Brasília, DF. Retrieved from http://www. planalto.gov.br/ccivil_03/constituicao/emendas/ emc/emc106.htm

Franzese, C. (2010). Federalismo cooperativo no Brasil: da Constituição de 1988 à constituição dos sistemas de políticas públicas. São Paulo, SP: FGV EAESP.

Franzese, C., \& Abrucio, F. L. (2013). Efeitos recíprocos entre federalismo e políticas públicas: os 
casos dos sistemas de saúde, assistência social e de educação. In G. Hocman, \& C. A. P. Faria (Orgs.), Federalismo e políticas públicas no Brasil (pp. 363388). Rio de Janeiro, RJ: Editora Fiocruz.

Geltzer, J. (2020, April 08). Trump's coronafederalism'pits states against each other. It's a disaster. Washington Post. Retrieved from https://www. washingtonpost.com/outlook/2020/04/08/trumpcorona-federalism/

Grin, E. J., \& Abrucio, F. L. (2017). La cooperación intermunicipal en Brasil frente al espejo de la historia: antecedentes críticos y la dependencia de la trayectoria después de la creación de la Ley de los Consorcios Públicos. Revista Políticas Públicas, 10(2), 1-27.

Grin, E. J., \& Abrucio, F. L. (2018). Las capacidades estatales de los municipios brasileños en un contexto de descentralización de políticas. Reforma y Democracia, 70, 93-126.

Halberstam, D. Comparative federalism and the role of the Judiciary (2008). In: G. A. Caldeira, R. Daniel Kelemen, \& K. E. Whittington. (Eds.), The Oxford handbook of law and politics (pp. 142-164). Nova York, NY: Oxford University Press.

Kettl, D. (2020). The Divided States of Federalism: Why federalism doesn't work. Princeton, NJ: Princeton Uiversity Press.

Lei Complementar no 173, de 27 de maio de 2020. (2020). Estabelece o Programa Federativo de Enfrentamento ao Coronavírus SARS-CoV-2 (Covid-19), altera a Lei Complementar no 101, de 4 de maio de 2000, e dá outras providências. Brasília, DF. Retrieved from http://www.planalto.gov.br/ ccivil_03/leis/lcp/lcp173.htm

Lima, R. S, \& Bueno, S. (2020, April 29). Homicídios pelo sétimo mês consecutivo no país. Retrieved from https://facesdaviolencia.blogfolha.uol.com. br/2020/04/29/homicidios-crescem-pelo-setimomes-consecutivo-no-pais/

Loughlin, J., Kincaid, J., \& Sweden, W. (2013). Handbook of Regionalism \& Federalism. London, UK; New York, NY: Routledge Taylor; Francis Group.

Medida Provisória 926, de 2020. (2020). Altera a Lei $\mathrm{n}^{\circ} 13.979$, de 6 de fevereiro de 2020, para dispor sobre procedimentos para aquisição de bens, serviços e insumos destinados ao enfrentamento da emergência de saúde pública de importância internacional decorrente do coronavírus. Brasília, DF. Retrieved from https:// www.congressonacional.leg.br/materias/medidasprovisorias/-/mpv/141144

Obinger, H., Leibfried, S., \& Castles, F. G. (2005). Federalism and the welfare state: new world and european experiences. Cambridge, UK: Cambridge University Press.

Organização para Cooperação e Desenvolvimento. (2020). The territorial impact of COVID-19: managing the crisis across levels of government. Retrieved from http://www.oecd.org/coronavirus/policy-responses/ the-territorial-impact-of-covid-19-managing-thecrisis-across-levels-of-government-d3e314e1/

Paquet, M., \& Schertzer, R. (2020). COVID-19 as a Complex Intergovernmental Problem. Canadian Journal of Political Science, 1-5. Retrieved from https://doi.org/10.1017/S0008423920000281

Pierson, P. (1995). Fragmented Welfare States: Federal Institutions and the Development of Social Policies. Governance: An International Journal of Policy and Administration, 8(4), 449-78.

Pleitgen, F. (2020, April 16). What Trump could learn from Angela Merkel about dealing with coronavirus. Retrieved from https://edition.cnn. com/2020/04/16/europe/merkel-trump-germanyfederalism-analysis-intl/index.html

Proposta de Emenda à Constituição 15, de 2015. (2015). Altera a Constituição Federal para estabelecer critérios de distribuição da cota municipal do Imposto Sobre Operações Relativas à Circulação de Mercadorias e sobre Prestações de Serviços de Transporte Interestadual e Intermunicipal e de Comunicação (ICMS), para disciplinar a disponibilização de dados contábeis pelos entes federados, para tratar do planejamento na ordem social e para dispor sobre o Fundo de Manutenção e Desenvolvimento da Educação Básica e de Valorização dos Profissionais da Educação (Fundeb); altera o Ato das Disposições Constitucionais Transitórias; e dá outras providências. Brasília, DF. Retrieved from https://www.camara.leg.br/proposicoesWeb/ fichadetramitacao?idProposicao $=1198512$ 
Proposta de Emenda à Constituição 188, de 2019. (2019). Altera arts. $6^{\circ}, 18,20,29-A, 37,39,48,62,68$, $71,74,84,163,165,166,167,168,169,184,198,208$, 212, 213 e 239 da Constituição Federal e os arts. 35, 107,109 e 111do Ato das Disposições Constitucionais Transitórias; acrescenta à Constituição Federal os arts. 135-A, 163-A, 164-A, 167-A, 167-B, 168A e 245-A; acrescenta ao Ato das Disposições Constitucionais Transitórias os arts. 91-A, 115, 116 e 117; revoga dispositivos constitucionais e legais e dá outras providências. Brasília, DF. Retrieved from https://www25.senado.leg.br/web/atividade/ materias/-/materia/139704

Ramirez de La Cruz, E. E., Grin, E. J., SanabriaPulido, P., Cravacuore, D., \& Orellana, A. (2020, JulyAugust). The Transaction Costs of the Governments' Response to the COVID-19 Emergency in Latin America. Public Administration Review, 80(4), pp. 683-695. Retrieved from https://onlinelibrary.wiley. com/doi/epdf/10.1111/puar.13259

Schmitt, C. (1992). O Conceito do Político. Rio de Janeiro, RJ: Editora Vozes.

Schnabel, J. (2015). The intergovernmental safeguard's capacity to prevent opportunism: evidence from eight federation. In Proceedings of 2015 ECPR General Conference, Montreal, Canada.
Segatto, C. I., \& Abrucio, F. L. (2018). Os múltiplos papéis dos governos estaduais na política educacional brasileira: os casos do Ceará, Mato Grosso do Sul, São Paulo e Pará. Revista de Administração Pública, 52(6), 1179-1193.

Soares, I. (2020, March 20). Bolsonaro critica governadores: 'Medidas extremas que não competem a eles. Correio Braziliense. Retrieved from https:// www.correiobraziliense.com.br/app/noticia/ politica/2020/03/20/interna_politica,835548/ bolsonaro-critica-governadores-medidas-extremasque-nao-competem-eles.shtml

Tulich, T., Rizzi, M., \& McGaughey, F. (2020). Cooperative Federalism, Soft Governance and Hard Laws in Australia's State of Emergency. Retrieved from https://verfassungsblog.de/fighting-covid-19legal-powers-and-risks-australia/

Urbinati, N. (2019). Me the People: How Populism Transforms Democracy. Cambridge, Massachusets: Harvard University Press.

Vasconcelos, R. (2020, April 02). Coronavirus: relembre o que Bolsonaro já falou sobre a pandemia. Retrieved from https://politica.estadao.com.br/ noticias/geral,coronavirus-o-que-bolsonaro-jafalou-ate-agora-sobre-a-pandemia,70003234776 


\section{Fernando Luiz Abrucio}

https://orcid.org/0000-0002-3883-9915

Ph.D. in Political Science; Professor from São Paulo School of Business Administration at Fundação Getulio Vargas (FGV EAESP). E-mail: fernando.abrucio@fgv.br

\section{Eduardo José Grin}

https://orcid.org/0000-0002-0488-8487

Ph.D. in Public Administration and Government; Professor from São Paulo School of Business Administration at Fundação Getulio Vargas (FGV EAESP). E-mail: eduardo.grin@fgv.br

\section{Cibele Franzese}

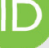

https://orcid.org/0000-0001-7441-2831

Ph.D. in Public Administration and Government; Professor from São Paulo School of Business Administration at Fundação Getulio Vargas (FGV EAESP). E-mail: cibele.franzese@fgv.br

\section{Catarina lanni Segatto}

https://orcid.org/0000-0002-5094-8225

Ph.D. in Public Administration and Government; Visiting Professor in the Postgraduate Program in Public Policy at the Federal University of ABC (UFABC). E-mail: catarina.segatto@gmail.com

\section{Cláudio Gonçalves Couto}

https://orcid.org/0000-0003-0153-1877

Ph.D. in Political Science; Professor from São Paulo School of Business Administration at Fundação Getulio Vargas (FGV EAESP). E-mail: claudio.couto@fgv.br 